\title{
Ethnic and Racial Identities of Second-Generation Black Immigrants in New York City
}

\section{Citation}

Waters, Mary C. 1994. Ethnic and racial identities of second-generation black immigrants in New York City. International Migration Review 28, no. 4: 795-820.

\section{Published Version}

http://dx.doi.org/10.2307/2547158

\section{Permanent link}

http://nrs.harvard.edu/urn-3:HUL.InstRepos:3686134

\section{Terms of Use}

This article was downloaded from Harvard University's DASH repository, and is made available under the terms and conditions applicable to Other Posted Material, as set forth at http:// nrs.harvard.edu/urn-3:HUL.InstRepos:dash.current.terms-of-use\#LAA

\section{Share Your Story}

The Harvard community has made this article openly available.

Please share how this access benefits you. Submit a story.

Accessibility 


\title{
Ethnic and Racial Identities of Second-Generation Black Immigrants in New York City
}

\author{
Mary C. Waters ${ }^{1}$ \\ Harvard University
}

This article explores the types of racial and ethnic identities adopted by a sample of 83 adolescent second-generation West Indian and Haitian Americans in New York City. The subjective understandings these youngsters have of being American, of being black American, and of their ethnic identities are described and contrasted with the identities and reactions of first-generation immigrants from the same countries. Three types of identities are evident among the second generation - a black American identity, an ethnic or hyphenated national origin identity, and an immigrant identity. These different identities are related to different perceptions and understandings of race relations and of opportunities in the United States. Those youngsters who identify as black Americans tend to see more racial discrimination and limits to opportunities for blacks in the United States. Those who identify as ethnic West Indians tend to see more opportunities and rewards for individual effort and initiative. I suggest that assimilation to America for the second-generation black immigrant is complicated by race and class and their interaction, with upwardly mobile secondgeneration youngsters maintaining ethnic ties to their parents' national origins and with poor inner city youngsters assimilating to the black American peer culture that surrounds them.

The growth of nonwhite voluntary immigrants to the United States since 1965 challenges the dichotomy which once explained different patterns of American inclusion and assimilation - the ethnic pattern of assimilation of immigrants from Europe and their children and the racial pattern of exclusion of America's nonwhite peoples. The new wave of immigrants includes people who are still defined "racially" in the United States, but who migrate to the United States voluntarily and often under an immigrant preference system which selects for people with jobs and education that puts them well above their "co-ethnics" in the economy. Do the processes of immigration and assimilation for nonwhite immigrants resemble the processes for earlier white immigrants? Or do these immigrants and their children face very different choices and constraints because they are defined racially by other Americans?

\footnotetext{
${ }^{1}$ This research was supported by a grant from the Russell Sage Foundation, and by a John Simon Guggenheim Fellowship. I would like to thank Maggi Apollon, Kayode Owens, Crystal Byndloss, Jimmy Phillippe, and Lisa Walke for research assistance. I am grateful for comments on an earlier version of this article from Christine Williams, Carolyn Boyes-Watson, Nancy Foner, Niobe Way, Bonnie Leadbeater, and three anonymous reviewers.
} 
This article examines a small piece of this puzzle - the question of the development of an "ethnic identity" among the second generation of black immigrants to the United States from the Caribbean. While there has been a substantial amount of interest in the identities and affiliations of immigrants from the Caribbean, there has been very little research on the identities of their children. The children of black immigrants in the United States face a choice about whether they will identify as black Americans or whether they will maintain an ethnic identity reflecting their parents' national origins. First-generation black immigrants to the United States have tended to distance themselves from American blacks, stressing their national origins and ethnic identities as Jamaican or Haitian or Trinidadian, but they also face overwhelming pressures in the United States to identify only as "blacks" (Stafford, 1987; Foner, 1987; Sutton and Makiesky, 1975; Woldemikael, 1989; Kasinitz, 1992). In fact, they have been described as "invisible immigrants" (Bryce-Laporte, 1972), because rather than being contrasted with other immigrants (for example, contrasting how Jamaicans are doing as compared with Chinese), they have been compared to black Americans. The children of black immigrants, because they lack their parents' distinctive accents, can choose to be even more invisible as ethnics than their parents. Second-generation West Indians in the United States will most often be seen by others as merely "American" - and must actively work to assert their ethnic identities.

The types of racial and ethnic identities adopted by a sample of secondgeneration West Indians ${ }^{2}$ and Haitian Americans in New York City are explored here, along with subjective understandings these youngsters have of being American, of being black American, and of their ethnic identities. After a short discussion of current theoretical approaches to understanding assimilation among the second generation, three types of identities adopted by members of the second generation are described and the different understandings and experiences of race relations associated with these different identities are traced. Finally this article suggests some implications for future patterns of identity development.

Immigration from the English-speaking islands of the Caribbean has been substantial throughout the twentieth century, but numbers of immigrants coming from the West Indies and Haiti really grew following the change in the immigration law in 1965 (Bryce-Laporte, 1987; Kasinitz, 1992). According to the 1990 census, there were 1,455,294 foreign-born blacks in the United States or 4.8 percent of blacks nationwide. The vast majority of these are from the Caribbean. Miami and New York City are the chief destination cities for these immigrants, and the concentration of

${ }^{2}$ The families of the teens were from 12 different countries including: Jamaica (31\%); Trinidad (21\%); Guyana (16\%); Barbados (10\%); Haiti (10\%); Grenada (5\%) and a few each from the smaller islands on Montserrat, Saint Thomas, Anguilla, Saint Lucia, Dominica and Nevis. 
foreign-born blacks and their children is much higher in these cities. Currently, about 25 percent of the black population in New York is foreign born, with a substantial and growing second generation (because the census does not ask a birthplace-of-parents question, it is impossible to know exactly how many second-generation West Indians there are currently in the United States). During 1990-1992, I conducted in-depth interviews of immigrants and their children in New York City, designed to explore assimilation patterns and issues of racial and ethnic identity.

The overall study was designed to explore the processes of immigrant adaptation and accommodation to the United States, to trace generational changes in adaptation and identification, and to explore the reactions of immigrants and their children to American race relations. Interviews with black and white Americans who interacted with the first and second generations were included in order to understand the dynamic and interactive processes of self- and other-identification and the development of ethnic attitudes and stereotypes. The first-generation respondents and their American co-workers were drawn from two worksites - unskilled workers at a food service company in downtown Manhattan and middle-class schoolteachers in the New York City school system. The entire study included in-depth interviews with 72 first-generation immigrants, 83 second-generation immigrants, 27 whites, and 30 native-born black Americans. ${ }^{3}$ In total, the study draws from 212 in-depth interviews that lasted between one and two hours. They were conducted by myself (a white female) and a team of three research assistants, two of whom are second-generation Caribbean Americans and one a black American.

Interviews with first-generation immigrants and their American co-workers reveal a great deal of tension between foreign-born and American-born blacks in both the working-class and the middle-class worksites. Longstanding tensions between newly arrived West Indians and American blacks have left a legacy of mutual stereotyping (see Kasinitz, 1992). The immigrants see themselves as hard-working, ambitious, militant about their racial identities but not oversensitive or obsessed with race, and committed to education and family. They see black Americans as lazy, disorganized, obsessed with racial slights and barriers, with a disorganized and laissez faire attitude toward family life and child raising. American blacks describe the immigrants as arrogant, selfish, exploited in the workplace, oblivious to racial tensions and politics in the United States, and unfriendly and unwilling to have relations with black Americans. The first generation believes that their status as foreign-born blacks is higher than American blacks, and they tend to accentuate their identities as immigrants. Their

\footnotetext{
${ }^{3}$ While there are many Spanish-speaking immigrants from the Caribbean who also define themselves or are defined by others as racially black, the identity choices for these people are quite different than for English-speaking immigrants. The first-generation respondents in this study were restricted to English-speaking immigrants.
} 
accent is usually a clear and unambiguous signal to other Americans that they are foreign born.

The dilemma facing the second generation is that they grow up exposed to the negative opinions voiced by their parents about American blacks and exposed to the belief that whites respond more favorably to foreign-born blacks. But they also realize that because they lack their parents' accents and other identifying characteristics, other people, including their peers, are likely to identify them as American blacks. How does the second generation handle this dilemma? Do they follow their parents' lead and identify with their ethnic identities as Jamaican or Haitian or West Indian? Or do they try to become "American" and reject their parents' ethnic immigrant identities? The second generation sample included 83 adolescents drawn from four sources designed to tap a range of class backgrounds and class trajectories. They include:

1) The public school sample: teenagers attending two public inner city high schools in New York City where I did extensive interviewing and participant observation (45 interviews);

2) The church school sample: teenagers attending Catholic parochial schools in the same inner city neighborhoods as the public high school (although most of these students were not themselves Catholic) (14 interviews);

3) The street-based sample: teenagers living in the same inner city neighborhood in Brooklyn who could not be reached through the school either because they had dropped out or would not have responded to interviews conducted in a formal setting (15 interviews); and

4) The middle-class sample: teenagers who had ties to this neighborhood who were now living there and attending magnet schools or colleges outside of the district or whose families had since moved to other areas of the city or suburbs (9 interviews).

The young people we talked to therefore include teens who are facing very limited socioeconomic mobility or downward social mobility (the inner city public school students and the street group), students in the church sample who are on an upward social trajectory and have a high chance of going to college, and teens whose families are doing well and who themselves would seem to have bright futures. Overall, 16 percent of the 83 teens were from very poor families on public assistance, 49 percent were from families with at least one parent working at a low wage job, and 35 percent were from middle-class families with at least one parent in a job requiring a college degree. The age of respondents ranged from 14-21. The average age was 17 . The vast majority were aged 16-18. We included teenagers who had spent at least three years in the United States and who had immigrated before age 16 . They included 34 (41\%) who comprise the classic second generation - born in the United States of immigrant parents. Another 14 
(17\%) immigrated to the United States before age 7 . The rest of the sample included 35 young people who had immigrated after age 7 and had spent at least three years in the United States. The actual age at immigration for these more recent immigrants varied from $7-15{ }^{4}$

\section{THEORETICAL APPROACHES TO ASSIMILATION}

Theories derived from the experiences of European immigrants and their children in the early twentieth century predicted that the longer the time spent in the United States, the more exposure to American culture, the more likely second-generation youths were to adopt an "American identity" and to reduce ties to the immigrant or ethnic identities and culture of their parents. This "straight line" assimilation model assumes that with each succeeding generation the groups become more similar to mainstream Americans and more economically successful. For instance, Warner and Srole's (1945) study of the ethnic groups in Yankee City (Newburyport, MA) in the early 1930s describes the generational march of the ethnic groups from initial residential and occupational segregation and poverty to residential, occupational and identificational integration and Americanization.

However, the situation faced by immigrant blacks in the 1990s differs in many of the background assumptions of the straight line model. The immigrants do not enter a society that assumes an undifferentiated monolithic American culture, but rather a consciously pluralistic society in which a variety of subcultures and racial and ethnic identities coexist. In fact, if these immigrants assimilate they assimilate to being not just Americans but black Americans. It is generally believed by the immigrants that it is higher social status to be an immigrant black than to be an American black. Second, the economic opportunity structure is very different now than at the beginning of the twentieth century. The unskilled jobs in manufacturing that gave opportunities for job mobility for the immigrants' children at the turn of the century have been lost as economic restructuring in the United States has shifted to a service economy (Gans, 1992). The immigrants also are quite varied in the skills they bring with them. Some arrive with advanced educations and professional qualifications to take relatively wellpaying jobs, which put them ahead of native American blacks (e.g., Jamaican nurses). Others are less skilled and face difficulties finding work in the United States. Finally, the degree of residential segregation faced by blacks

\footnotetext{
${ }^{4}$ Rumbaut (1991) and Rumbaut and Ima (1988) have suggested using the term "generation 1.5" for youngsters born abroad but educated in whole or part in the United States Others have used second generation to include both children of immigrants and the immigrants who came as children (Portes and Zhou, 1993; Jensen, 1990). Circular migration makes these categories even more difficult to define as some youngsters who were born in the United States may have spent more time in their parents' native country (having returned there often to live for short periods) than other youngsters who were born abroad but do not return often to their native country.
} 
in the United States, whether foreign born or American born, has always been, and continues to be, of a much higher order than the segregation faced by foreign-born white immigrants (Lieberson, 1980; Massey, 1990). Thus, even with occupational mobility it is not clear that blacks would be able to move into higher status neighborhoods in the orderly progression that Warner and Srole (1945) describe in their Yankee City study of European ethnic succession. A further complication for the black second generation is that part of being a black American involves dealing with American racism. Because immigrants and black Americans report a large difference in the perception and expectation of racism in American society, part of becoming American for the second generation involves developing a knowledge and perception of racism and its effects and subtle nuances.

A few researchers have examined the identification of second-generation Caribbean blacks. In a study of Haitian Americans in Evanston, Illinois, in the 1970s, Woldemikael (1989) found that the second generation mostly identified as American black. He found that the first generation stressed their differences from American blacks, but the second generation faced pressure to become "not so much American, but Afro-American"; "AfroAmerican students pressured the Haitian students to adopt their dialect, speech and dress styles and ways of behavior" (Woldemikael, 1989:94). In an in-depth study of the experience of several West Indian children in New York City schools, Michael (1990) also stresses the influence on these children of the Afro-American children in school and on the streets.

New theories describing the experiences of becoming American for recent immigrants and their children (Gans, 1992; Portes and Zhou, 1993) stress the multiple and contradictory paths which can be followed by secondgeneration children. Some achieve socioeconomic success while retaining strong ethnic attachments and identities, while others assimilate to American subcultures with limited socioeconomic mobility. In a 1992 article entitled "Second Generation Decline," Herbert Gans outlines several scenarios of possible socioeconomic and social integration of the post-1965 second generation. He speculates that the children of the new immigrants could face socioeconomic decline relative to their parents' positions because the children of immigrants might refuse to accept the low-level, low-pay jobs at which their parents work.

The other possibility is that the youngsters who do not "become American" and adopt the negative attitudes toward school, opportunity, hard work and the "American dream" that their American peers have adopted, but rather stay tied to their parents' ethnic community and values, will end up doing better. Gans (1992) thus suggests that straight-line theory could be turned on its head, with "the people who have secured an economically viable ethnic or other niche acculturating less than did the European second and third generations" and those without such a niche "experiencing the 
poverty and joblessness of second-generation decline and becoming American faster than other second-generation ethnics" (p. 188).

Using material from a number of different ethnographic case studies, as well as a survey of second-generation school children in Miami and San Diego, Portes and Zhou (1993) make a similar argument. They describe the different outcomes of the different groups of second-generation youth as "segmented assimilation." They argue that the mode of incorporation of the first generation creates differential opportunities and cultural and social capital in the form of ethnic jobs, networks and values that create differential pulls on the allegiances of the second generation. For those immigrant groups who face extreme discrimination in the United States and who reside in close proximity to American minorities who have faced a great deal of discrimination, reactive ethnicity emerges in the first generation. The second-generation youth whose ties to American minorities are stronger and whose parental generation lacks the degree of social capital to provide opportunities and protection for the second generation are likely to develop the "adversarial stance" that American minorities such as poor blacks and Hispanics hold toward the dominant white society. This adversarial stance stresses that discrimination in the United States is very strong and devalues education as a vehicle of advancement. For those groups who come with strong ethnic networks, access to capital, and less ties to minorities in the United States, linear ethnicity characterizes the first generation. Linear ethnicity creates social capital - the networks of social ties from church and voluntary organizations creates ties to job opportunities and interlacing ties which reinforce parental authority and values vis-à-vis the second generation. These groups resist acculturation to the United States and end up providing better opportunities for the second generation.

Portes and Zhou (1993) use the experiences of Chinese and Koreans as examples of immigrants who develop linear ethnicity and develop strong ethnic communities in the United States. They are contrasted with the example of Haitians in Florida who are pressured to adapt to the black American peer culture in their schools. Portes and Zhou stress that the adversarial stance of this peer culture directly contradicts the immigrant parents' expectations of upward mobility and educational success for their offspring. The second generation that casts their lot with America's minority groups will most likely be at risk of downward social mobility. Association with ethnic minorities could prove "a ticket to permanent subordination and disadvantage for the youngsters who adopt it" (p. 96).

Both Gans and Portes and Zhou stress the negative consequences in terms of aspirations and ultimate socioeconomic outcomes of adopting an "American" minority attitude toward school and work opportunities. Portes and Zhou call this an "adversarial outlook." John Ogbu (1990) describes a similar "minority" outlook as an oppositional frame of reference that he ties 
to historical roots in the involuntary incorporation of minority groups into the society. These ideas are enormously helpful in explaining and understanding the experiences of the second-generation West Indian youth in this study. In fact, the youth described here, who seem to be on different socioeconomic trajectories, understand their racial and ethnic identities differently. Some of the adolescents we interviewed agree with their parents that the United States holds many opportunities for them. Others disagree with their parents because they believe that racial discrimination and hostility from whites will limit their abilities to meet their goals. By contrasting the ideas these youngsters have about their own identities and the role of race in American society, I suggest that social capital among the first generation and the type of segmented assimilation among the second generation varies within ethnic groups as well as between them. Some Jamaican Americans, for example, are experiencing downward social mobility while others are maintaining strong ethnic ties and achieving socioeconomic success.

The key factor for the youth I studied is race. The daily discrimination that the youngsters experience, the type of racial socialization they receive in the home, the understandings of race they develop in their peer groups and at school affect strongly how they react to American society. The ways in which these youngsters experience and react to racial discrimination influences the type of racial/ethnic identity they develop.

\section{PATTERNS IN THE SECOND GENERATION}

The interviews suggest that while there is a great deal of individual variation in the identities, perceptions and opinions of these teens, their racial and ethnic identities can be classified into three general types: identifying as Americans, identifying as ethnic Americans with some distancing from black Americans, or maintaining an immigrant identity that does not reckon with American racial and ethnic categories.

A black American-identified identity characterized the responses of approximately 42 percent of the 83 second-generation respondents interviewed. These youngsters identified with other black Americans. They did not see their "ethnic" identities as important to their self-image. When their parents or friends criticized American blacks or described what they perceived as fundamental differences between Caribbean-origin people and American blacks, these youngsters disagreed. They tended to downplay an identity as Jamaican or Trinidadian and described themselves as American.

Another 30 percent of the respondents adopted a very strong ethnic identity which involved a considerable amount of distancing from American blacks. It was important for these respondents to stress their ethnic identities and for other people to recognize that they were not American blacks. These respondents tended to agree with parental judgements that there 
were strong differences between Americans and West Indians. This often involved a stance that West Indians were superior to American blacks in their behaviors and attitudes.

A final 28 percent of respondents had more of an immigrant attitude toward their identities than either the American-identified youth or the ethnic-identified youth. Most, but not all, of these respondents were more recent immigrants themselves. A crucial factor for these youngsters is that their accents and styles of clothing and behavior clearly signaled to others that they were foreign born. In a sense, their identity as an immigrant people precluded having to make a "choice" about what kind of American they were. These respondents had a strong identity as Jamaican or Trinidadian, but did not evidence much distancing from American blacks. Rather their identities were strongly linked to their experiences on the islands, and they did not worry much about how they were seen by other Americans, white or black.

A number of factors influence the type of identity the youngsters develop. These include the social class background of the parents, the social networks the parents were involved in, the type of school the child attended, and the family structure. All of these factors affect the ability of parents and other family members to shield children from neighborhood peer groups that espouse antischool values.

There tended to be a strong relationship between the type of identity and outlook on American race and ethnic relations that the youngsters developed and their social class background and/or their social class trajectory. The ethnic-identified youngsters were most likely to come from a middleclass background. Of the total of 83 second-generation teens and young adults interviewed, 57 percent of the middle-class ${ }^{5}$ teens identified ethnically, whereas only 17 percent of the working class and poor teens identified ethnically. The poorest students were most likely to be immigrant or American-identified. Only one out of the twelve teens whose parents were on public assistance identified ethnically. The American-identified, perhaps not surprisingly, were also more likely to be born in the United States - 67 percent of the American-identified were born in the United States, as opposed to only 13 percent of the immigrant-identified or 42 percent of the ethnically-identified.

Parents with more education and income were able to provide better schools for their offspring. Among the respondents, some of the middle class had moved from the inner city neighborhoods they had originally settled in to middle-class neighborhoods in the borough of Queens or to suburban areas where the schools were of higher quality academically and

\footnotetext{
${ }^{5}$ Middle class was defined as having at least one parent with a college degree or a professional or business position. Working class was defined as a parent with a low-skill job; poor were students whose parents were not currently employed.
} 
more likely to be racially integrated. Other middle-class parents sent their children to Catholic parochial schools or to citywide magnet schools such as Brooklyn Tech or Stuyvesant. They were thus far more likely to attend schools with other immigrant children and with other middle-class whites and blacks, although some of the Catholic high schools the students attended were also all black in enrollment.

The children of middle-class parents who did attend the local high schools were likely to be recent immigrants who had an immigrant identity. Because of their superior education in the West Indies, these students were the best in the local high schools, attended honors classes and were bound for college. The children of middle-class parents who were American identified and pessimistic about their own future opportunities and adopted antischool ideologies were likely to have arrived early in their lives and to have attended New York City public schools in inner city areas from an early age.

The social networks of parents also influenced the type of identity the children developed. Regardless of social class, parents who were involved in ethnic voluntary organizations or heavily involved in their churches seemed to instill a strong sense of ethnic identity in their children. Parents whose social networks transcended neighborhood boundaries seemed to have more ability to provide guidance and social contacts for their children.

The two neighborhood schools where we interviewed were among the five most dangerous schools in New York City - they were inadequate facilities with crumbling physical buildings, high drop-out rates, and serious problems with violence. Both schools were all minority, with over 90 percent of the student body composed of black students, both American and foreign born. The students who attended these schools and were not in the separate honors tract (which was overwhelmingly filled with newly arrived immigrants) faced very limited future options, even if they did manage to graduate.

Finally, the family structure and the experience of migration itself has a profound effect on the degree of control parents have over teenage children. Many families are composed of single working mothers and children. These mothers have not been able to supervise their children as much as they would like, and many do not have any extended family members or close friends available to help with discipline and control. Even families with two spouses present often have been apart for long periods because one spouse preceded the family in migration. Often children have been left in the islands or sent ahead with relatives to New York and sometimes as teenagers reunited with parents who then try to assert authority. The generational conflict which often ensues tends to create greater pressure for students to want to be "American" to differentiate themselves from parents.

Each of the different identity types adopted by these teens are described below. 


\section{THE ETHNIC RESPONSE}

All of the teenage respondents reported comments by their parents about American blacks which were very similar to those recorded in our interviews with the first generation. The differences were in how the teens interpreted what their parents were saying. In general, the ethnic-identified teens agreed with their parents and reported seeing a strong difference between themselves and black Americans, stressing that being black is not synonymous with being black American. They accept their parents' and the wider society's negative portrayals of poor blacks and wanted to avoid any chance that they will be identified with them. They described the culture and values of lower-class black Americans as including a lack of discipline, lack of a work ethic, laziness, bad child-rearing practices and lack of respect for education. They contrast these with their parents' ethnic groups' values which include valuing education, strict discipline for children, a strong work ethic and social mobility. They try to impress to others that they are Jamaican or Haitian and most definitely not American black. This allows them less dissonance with their parents' negative views of American blacks. They do not reject their parents' culture and identities, but rather reject the American social system that would identify them as American black and reject strongly the African-American peer group culture to which they would be assigned by whites and others if they did not consciously transmit their ethnic identities.

Although society may define the second generation on the basis of skin color, the second-generation ethnic teens believed that being black American involves more than merely having black skin. One young woman criticized American blacks in this way:

Some of them [black Americans] think that their heritage includes not being able to speak correctly or walk correctly, or act loud and obnoxious to make a point. I don't think they have to do that. Just when I see black Americans, it depends on how I see you on the street. Walking down the street with that walk that moves a little bit too much. I would say, I'd think you dropped out of high school.

These teens also differentiated themselves from black Americans in terms of their sensitivity to racism, real or imagined. Some of the ethnic-identified second generation echo the feelings we heard from the first generation that American blacks are too quick to use race as an explanation or excuse for not doing well:

There was a time back in the 40 s and 50 s and 60 s or whenever when people was actually trying to keep down black people and stuff like that. But, you know, some black people now, it's like they not actually trying to make it better, you know? Some are just like, people are like, oh, this place is trying to keep me down, and they sulk and they cry about it, and they're not really doing that much to help themselves. ... It's just like hyping the problem if they keep [saying] everything is racial, everything is racial. 
The second-generation teens who are doing well try to understand how it is that they are so successful when black Americans are not - and often they chalk it up to family values. They say that their immigrant families have close-knit family values that stress education. Aware of, and sometimes sharing, the negative images of black Americans that the whites they encounter believe, the second generation also perceives that whites treat them better when they realize they are not "just" black Americans. When asked if they benefited ever from their ethnicity, they responded "yes": "It seems white Americans don't tend to put you in the same category as black Americans." Another respondent said:

The West Indians tend to go that extra step because they, whites, don't usually consider them really black Americans, which would be working class. They don't consider them, I guess, as black. They see them as a person.

The dilemma for the second generation is that while they have a strong sense of their own identities as very different from black Americans, this was not clear to other people. Often both whites and blacks saw them as just black Americans and did not notice that they were ethnically different. When people did comment on their ethnic difference it was often because of the way they talked and the way they walked. These were two characteristics which were cited as reasons whites and other blacks gave for thinking those of the second generation weren't "really black." Whites tend to let those of the second generation know that they think of them as exceptions to the rule, with the rule being that most blacks are not good people. However, these young people also know that unless they tell people of their ethnicity, most whites have no idea they are not black Americans.

Many of these teens coped with this dilemma by devising ways to telegraph their identities as second-generation West Indians or Haitians. One girl carried a Guyanese map as part of her key chain so that when people looked at her keys they would ask her about it and she could tell them that her parents were from Guyana. One young woman described having her mother teach her an accent so that she could use it when she applied for a job or a place to live. Others just try to work it into the conversation when they meet someone. This means that their self-identification is almost always at odds with the identifications others make of them in impersonal encounters in American society and that as a result they must consciously try to accentuate their ethnic identity:

$\mathrm{Q}$ : When a form or survey asks for your race what do you put down?

A: Oh boy, that is a tough one. It's funny because, you know, when we fill applications I never know what to check off, you know. I'm serious. 'Cause they have Afro-American, but they never have like Caribbean. They do have white, Chinese. To tell the truth, I would like to be called Caribbean, West Indian. Black West Indian. 
The teens who were around many black Americans felt pressure from their peers to be part of the group and to identify as black American. These teens would consciously talk about passing for American at some points and passing for Haitian or Jamaican at others by changing the way they talked or acted:

When I'm at school and I sit with my black friends and, sometimes I'm ashamed to say this, but my accent changes. I learn all the words. I switch. Well, when I'm with my friends, my black friends, I say I'm black, black American. When I'm with my Haitian-American friends, I say I'm Haitian. Well, my being black, I guess that puts me when I'm with black Americans, it makes people think that I'm lower class. ... Then, if I'm talking like this [regular voice] with my friends at school, they call me white.

\section{THE AMERICAN-IDENTIFIED SECOND GENERATION}

The American-identified second-generation teenagers differed in how little they stressed their immigrant or ethnic identities to the interviewers. They follow a path which is more similar to the model posed in the straight line theory. They stress that they are American because they were born here, and they are disdainful of their parents' lack of understanding of the American social system. Instead of rejecting the black American culture, it becomes their peer culture and they embrace many aspects of it. This brings them in conflict with their parents' generation, most especially with their parents' understandings of American blacks. The assimilation to America that they undergo is most definitely to black America; they speak black English with their peers, they listen to rap music, and they accept the peer culture of their black American friends. They are aware of the fact that they are considered black American by others and that they can be accused of "acting white" if they don't speak black English and behave in particular ways. Most included their ethnic identities as background, but none of them adopted the stance that they were not, in a major sense, black American. When asked about ethnic background and how other people think of them, one respondent replied:

Q. What is your ethnic background?

A. I put down American because I was born up here. I feel that is what I should put down....

Q. What do other people think you are?

A. Black American because if I don't say. . . L Like if they hear my parents talk or something they always think they are from Jamaica. ... But they just think I am black American because I was born up here.

Many of these teens discuss how they don't control how others see them:

Some people just think I am American because I have no accent. So I talk like American people. I don't talk Brooklynese. They think I am from down south or something. ... A lot of people say you don't look Haitian. I think 
I look Haitian enough. I don't know, maybe they are expecting us to look fresh off the boat. I was born here and I grew up here, so I guess I look American and I have an American accent.

Q. If people think you are black American do you ever do anything about it?

A. No, I don't. If they ask me if I am American, I say yes. If they ask me where my parents are from, I tell them Haiti.

In fact, they contrast being a black American as being more stylish and "with it" than being from the islands:

I consider myself a black American. When I think of a black American I don't think of them as coming from the West Indies.

$\mathrm{Q}$. Any characteristics that come to mind?

A. I would not think of someone in a suit. I would think of a regular teenager. I would think of a regular person. I think of someone that is in style.

Q. What about someone from the islands?

A. Jamaicans. They dress with neon colors. Most of the girls wear gold and stuff like that.

Some of the young people told us that they saw little if any differences between the ethnic blacks and the American blacks. Many stressed the Caribbeanization of black New York and described how all the Americans were interested in being Caribbean now:

It use to be Jamaicans and American blacks did not get along because everyone was afraid of Jamaicans. But now I guess we are closer now. You tell an American that you are Jamaican and it is no big deal. Americans are acting more like Jamaicans. Jamaicans are acting like Americans.

Q. What do you mean by acting like each other?

A. Sure there are a lot of Americans out there speaking Patois. And then all the Jamaicans are coming over here and they are like "Yo, what's up" and they are like that. Pretty soon you can't really tell who is Jamaican and who is American.

However, the parents of the American-identified teens have expressed to their children the same negative impressions of American blacks that the ethnic-identified teens reported. These teenagers report many negative appraisals of American blacks by their parents:

They always say Haiti is better in this way or in that way. They say the kids here have no respect. The kids here are brought up without any supervision. My father is always talking about they [American blacks] be hanging out on the corner. And he says you won't find Haitians doing that. My mom always says you will marry a Haitian. Why are you talking to those American boys?

This young Haitian-American teen tries to disagree with her mother and to temper her mother's interpretations of American blacks:

Q. Are there any characteristics or traits that come to mind about Haitian Americans? 
A. Not really. I don't really - cause most people are Haitian American if they are born here. . . . Like me, I don't know if I act like a Haitian or do I have Haitian characteristics, but I'm mostly - like everything I do or like is American. My parents, they do not like American blacks, but they feel that they are lazy. They don't want to work and stuff like that from what they see. And I feel that, um, I feel that way too, but sometimes it won't be that person's fault, so I try to stick up for them. And my mother is like, yeah, you're just too American.

In marked contrast to the ethnic-identified teens, though, the Americanidentified teens either disagreed with their parents' statements about American blacks, reluctantly agreed with some of it but provided qualifications, or perhaps most disturbingly accepted the appraisals as true of American blacks in general and themselves as American blacks. This young Trinidadian American swallows her parents' stereotypes and directly applies them to herself:

Q. How close do you feel in your ideas about things to West Indians?

A. Not very close. My feelings are more like blacks than theirs. I am lazy. I am really lazy and my parents are always making comments and things about how I am lazy. They are always like, in Trinidad you could not be this lazy. In Trinidad you would have to keep on working.

The fact that the teens are identifying as American and that their parents have such negative opinions of Americans causes some conflict. The teens either adopt a negative opinion of themselves or disagree with their parents' assessments of American blacks. But it is not just their parents who criticize black Americans. These youngsters are very aware of the generalized negative view of blacks in the wider culture. In answer to the question "do whites have an image of blacks," all of them responded that whites had a negative view of blacks seeing them as criminal, lazy, violent and uncaring about family. Many of the teenagers prefaced their remarks by saying that they did not know any whites, but that they knew this is what whites thought through the mass media and through the behaviors of whites they encountered in buses, trains and stores. This mostly involved incidents like whites protecting their handbags when the teenagers arrived or store clerks following them and expecting them to shoplift. This knowledge that the society in which they live devalues them because of their skin color and their identity affected these teens deeply.

\section{THE IMMIGRANT-IDENTIFIED TEENS}

The more recently arrived young people who are still immigrant-identified differed from both the ethnic and the American-identified youth. They did not feel as much pressure to "choose" between identifying with or distancing from black Americans as did either the American or the ethnic teens. Strong in their identities with their own or their parents' national origins, they were neutral toward American distinctions between ethnics and black Americans. They tended to stress their nationality or their birthplace as defining their 
identity. They also pointed to their experiences growing up and attending school in a different country. This young man had dreadlocks and a strong Jamaican accent. He stresses his African roots and lets his Jamaican origin speak for itself:

Q. What is your ethnicity? For example, when forms or surveys ask what your ethnic group or ancestry is what do you put?

A. African.

Q. Do you ever put Jamaican or anything?

A. No, not really. Only where Jamaican comes up is if someone asks where you're from. I'll say I am from Jamaica.

Q. What do people usually think you are?

A. They say I am Jamaican.

Q. They know that immediately?

A. Yeah.

Q. How do they know?

A. I change my voice. I don't have to tell them. I think it's also because of my locks sometimes and the way I carry myself, the way I dress.

While an ethnic-identified Jamaican American is aware that she might be seen by others as American and thus actively chooses to present herself as Jamaican, an immigrant-identified Jamaican could not conceive of herself as having a choice, nor could she conceive of being perceived by others as American. While an ethnic-identified teen might describe herself as Jamaican American, for the immigrant teen Jamaican would be all the label needed. Most teens in this category were recent immigrants themselves. The few U.S.-born teens classified as immigrant-identified had strong family roots on the islands, were frequent visitors to the islands, and had plans to return to live there as adults. A crucial factor that allows these youngsters to maintain this identity is that their accents and styles of clothing and behavior clearly signaled to others that they were foreign born.

Q. How important is it to you that your friends think of you in terms of your ethnicity?

A. Oh, very important. You know, I try hard not to lose my roots, you know, when I come to the United States. A lot of people who come here try to lose their accent, you know. Even in the workplace, you know, because they fear what other people might think of them. Even in the workplace. $\mathrm{Me}$, I never try to change, you know, the way I am. I always try to, you know, stay with them, the way of my culture.

Q. So it's something you want people to recognize?

A. Yeah, definitely, definitely, absolutely.

Q. Why?

A. Why? I'm proud of who I am, you know. I'm proud of where I'm from and I'm not going to change because somebody might not like the way I walk, talk or dress, you know. 
The importance of birthplace was stressed repeatedly by the immigrantidentified as they stressed their difference from American-born co-ethnics:

Q. What would you put on a form or survey that asked about your ethnicity?

A. I'll say I'm Jamaican. You gotta say where you come from.

Q. And do you think of yourself more as a Jamaican or more as an American?

A. I think of more of a Jamaican 'cause it's, I wasn't born here. I was born in Jamaica and was there for fourteen years.

$\mathrm{Q}$. And what about kids who are born in America, but their parents were born in Jamaica?

A. Well, you see that is the problem. You see, kids whose parents are Jamaican, they think that, well, they are Jamaican. They need to recheck that they're Americans 'cause they was born in the country and they wasn't born outside the country. So I think they should, you know, know more about American than Jamaican.

Some who adopt this strong identity with the immigrant country were born in the United States, but the combination of strong family roots on the island, frequent visits, and plans to go live there when they are older allows them to think of themselves as not really American at all. This is especially easy to do in the public high schools where there are large numbers of freshly arrived youngsters from the islands.

Q. What do you think your race is?

A. Well, I'm black. I consider myself black. I don't consider myself black American, Afro-American and stuff like that because it's hard to determine, you know, for a person as an individual to determine himself to be Afro-American. ... I'll be more a Guyanese person because certain things and traditions that I am accustomed to back home, it's still within the roots of me. And those things have not changed for a long period of time, even though you have to adapt to the system over here in order to get ahead and cope with what is going on around you.

While the ethnics tended to describe people treating them better when they described their ethnic origins, and the Americans tended to stress the antiblack experiences they have had and the lack of difference between the foreign born and the American, the immigrant teens spoke about anti-immigrant feelings and discrimination and responded with pride in their national origins.

\section{CONTRASTING IDENTITIES}

In some sense one can see each of these identities as being an embrace of a particular identity, as well as an opposition to another identity. The American-identified youth are in fact assimilating to the American black subculture in the neighborhood. It is the American black cultural forms they are adapting to, and they do so in distinction to their parents' ethnic 
identities and the wider mainstream white identities. These students adopt some of the "oppositional" poses that American black teenagers have been observed to show toward academic achievement: the idea of America, the idea of opportunity, and the wider society (Ogbu, 1990; Fordham, 1988; Portes and Zhou, 1993). They are also opposed to their parents' outlooks and ideas, stressing that what worked as an outlook and a life strategy and a child-raising technique in the islands does not work in the United States. These teens tend to adopt a peer culture of racial solidarity and opposition to school authorities. What is clear from the interviews is that this stance of opposition is in part a socialized response to a peer culture, but the vast majority of it comes about as a reaction to their life experiences. Most specifically, the teens respond to their experiences with racial discrimination and their perceptions of blocked social mobility. The lives of these youngsters basically lead them to reject the immigrant dream of their parents toward individual social mobility and to accept their peers' analysis of the United States as a place with blocked social mobility where they will not be able to move very far.

The American-identified teens do not seem to be aware of the scholarly literature and the perceptions described by the ethnic and immigrant youngsters that the foreign born are higher social status than the American born. In the peer culture of the neighborhood and the school, these teenagers describe a situation in which being American is higher social status than being ethnic. For instance, several girls described "passing" as black American in order not to be ridiculed or picked on in school.

I used to be scared to tell people that I was Haitian. Like when I was in eighth grade there were lots of Haitians in the ESL classes, and people used to beat them up. They used to pick on them. I said to myself I am going to quiet down, say I am American.

When asked about the images others held of being from the islands, most of the teens described neutral attributes, like styles of dress. However, many who identified as Americans also described negative associations with the immigrants' identities. The Jamaicans said most people thought of drug dealers when they thought about Jamaicans. A few of the teens also intimated that the people from the islands were backwards in not knowing how to live in a big city, both in terms of appreciating the wonders of the city and in terms of being street smart in avoiding crime and hassles with other people. In terms of the former attribute, the teens described people from the islands who were not accustomed to shopping in big malls or having access to a wide variety of consumer goods.

Not one of the American-identified teens voiced the opinion of the overwhelming majority of the ethnic teens that whites were more likely to like the foreign born. In part, this reflected the differences the groups had in their contact with whites. Most of the inner city ethnic-identified teens 
had almost no contact with whites, except for teachers. They also are in schools where the vast majority of the students are foreign born or second generation. The larger number of middle-class teens who were ethnic-identified were more likely to have white classmates in citywide magnet high schools, in parochial schools or in suburban schools or workplaces.

The inner city American-identified teens also voiced more positive appraisals of black Americans than did the immigrant or the ethnic-identified teens. Their descriptions also reflect the reality of living in neighborhoods where there is crime and violence. A majority of the American-identified teens said that a good trait of black Americans is that they work hard and they struggle. These are the very same children whose parents describe black Americans primarily as lazy and unwilling to take advantage of the opportunities available to them. The children seem to be perceiving a reality that the parents cannot or will not.

Many of these teens live in neighborhoods that are all black and attend schools that are all black, too. So, aside from teachers, these young people have almost no contact with white Americans. This does not stop them from absorbing the fact that whites have negative stereotypic views of blacks. But unlike the middle-class blacks who come in contact with whites who tell them that they are "good blacks," these youths live in the urban areas that are associated with crime, they dress like the typical black urban youth, and they talk with Brooklyn accents and black American slang. When they do encounter whites in public places, the whites do not ask about their parents' backgrounds:

Q. Have you ever experienced any discrimination or hostility in New York?

A. From being Trinidadian no. But because of being black, you know, everybody stereotypes. And they say "blacks, they tend to steal, and stuff like that." So, like, if I am walking down the street and a white lady go by and they smile and I smile. They put their bag on the other side.

The parents of these teens grew up in situations where blacks were the majority. The parents do not want their children to be "racial" in the United States. They define "being racial" as being overly concerned with race and with using race as an excuse or explanation for lack of success at school or on the job. The first generation tends to believe that, while racism exists in the United States, it can be overcome or circumvented through hard work, perseverance and the right values and attitudes. The second generation experiences racism and discrimination constantly and develops perceptions of the overwhelming influence of race on their lives and life chances that differs from their parents' views. These teens experience being hassled by police and store owners, not being given jobs, even being attacked on the streets if they venture into white neighborhoods. The boys adopt black American culture in their schools, wearing flattops, baggy pants, and certain types of jewelry. This contributes to the image that they project of the "cool 
pose" which in turn causes whites to be afraid of them. This makes them angry and resentful. The media also tells these youngsters that blacks are disvalued by American society. While parents tell their children to strive for upward mobility and to work harder in the face of discrimination, the American-identified teens think their chances of success by doing that are very slim.

This causes a wide gulf between the parents and their children. These parents are absolutely terrified of their children becoming Americans. For the children to be American is to have freedom from the strict parental controls of the immigrant parents. This is an old story in the immigrant saga that one can see in novels and movies about conflicts between Jewish and Italian immigrants and their children. But the added dimension in this situation is that these parents are afraid of the downward social mobility that becoming an American black represents to them. And these parents have that idea reinforced constantly by whites who tell them that they are better than American blacks.

One question I asked about how things had changed since the civil rights movement shows the different perceptions of the teens about race in United States society. The ethnic-identified gave answers I suspect most white Americans would give. They said that things are much better for blacks now. They state that they now can ride at the front of the bus and that they can go to school with whites. The irony, of course, is that I was sitting in an all-black school when they told this story. The vast majority of the American-identified teens state that things are not better since the civil rights movement. They think that the change is that the discrimination now is "on the down low," covered up, more crafty. Some pointed out that we were in an all-black school. The result of these different world views is that the parents' view of an opportunity structure that is open to hard work is systematically undermined by their children's peer culture and more importantly, by the actual experiences of these teens.

On the other hand, the ethnic-identified teens, whose parents are more likely to be middle class and doing well or who attend parochial or magnet schools and not the substandard neighborhood high schools, see clearer opportunities and rewards ahead, despite the existence of racism and discrimination. Their parents' message that hard work and perseverance can circumvent racial barriers does not fall on unreceptive ears. The ethnic-identified youngsters embrace an ethnic identity in direct line from their parents' immigrants identity. Such an identity is basically in part in opposition to their peers' identities and in solidarity with their parents' identities. These youngsters stress that they are Jamaican Americans and that, while they may be proud of their racial identity as black, they see strong differences between themselves and black Americans. They specifically see their ethnic identities as keys to upward social mobility, stressing, for 
instance, that their parents' immigrant values of hard work and strict discipline help them to succeed in the United States when black Americans fail. This ethnic identity is very much an American-based identity - it is in the context of American social life that these youngsters base their assumptions of what it means to be Jamaican or Trinidadian. In fact, often the pan-ethnic identity as Caribbean or West Indian is the most salient label for these youngsters, as they see little differences among the groups and it is more important to differentiate themselves as second-generation nonblack Americans. The distancing that these teens show from black Americans often leads them to accept many negative stereotypes of black Americans. These youngsters tend to have ethnic friends from a West Indian background, white American friends, and very few, if any, black American friends.

The immigrant-identified teens are different from either of the other two, in part because of how they think about who they are not, as well as how they think about who they are. These teens have a strong identity as Jamaican or Trinidadian, but this identity tends to be related to their interactions with other Jamaicans or Trinidadians rather than their interactions with black or white Americans. These youngsters identify with their homelands or their parents' homelands, but not in opposition to black Americans or in opposition to white Americans. They tend to be immersed in the immigrant community, to have friends who are all the same ethnicity or from other islands. They tend to be more recent arrivals. Unlike the ethnic-identified, however, they do not distance themselves from American blacks, and they have neutral or positive attitudes and relations with them. At the same time, they see themselves as different from, but not opposed to, black Americans.

These identities are fluid and change over time and in different social contexts. There are cases we found of people who describe being very black American-identified when they were younger and who became more immigrant-identified when they came to high school and found a large immigrant community. Most new arrivals to the United States start out as immigrant-identified, and the longer they are in the United States the more they begin to think of themselves in terms of American categories. The kind of social milieu the child faces, especially the school environment, has a strong influence on the outcome. A school with many black Americans leads to pressure to identity racially; likewise a neighborhood and school with many immigrants makes it possible to avoid thinking much about American categories. In the face of much pressure in the neighborhood school environment not to follow the rules and not to succeed academically, youngsters who are doing well in school and do value education increasingly come to stress their ethnic backgrounds as an explanation for their ambition and success.

The American racial classification system which tends to push toward an either/or designation of people as black or white tends to make the immi- 
grant option harder to hold onto. When others constantly identify the individual as a black and refuse to make distinctions based on black ethnicity, there tends to be pressure for the individual to adapt their identity to that outside identification - either to say "Yes, I am black," and to accept categorization with black Americans or to resent the characterization and strongly make an ethnic identification as Trinidadian American. The American myopia about ethnic differences within the black community makes the middle ground immigrant identity unstable. Because every young person is aware of the negative images held by whites and the wider society of black Americans, the acceptance of an American black identity also means the acceptance of the oppositional character of that identity. Oppositional identities, as Ogbu (1990) clearly argues, are self- and group-affirming identities for stigmatized groups - defining as good and worthy, traits and characteristics which are the opposite of those valued by the majority group. This tends to operate to downwardly level the aspirations of the teens.

\section{IMPLICATIONS OF THE PATTERNS}

Some of the distancing shown by the ethnic-identified teens in the sample vis-à-vis underclass black identity and behaviors is the same for middle-class black Americans. Elijah Anderson (1990) has noted that middle-class blacks in a gentrifying neighborhood in Philadelphia use various verbal and nonverbal strategies to convey to others that they are not from the ghetto and that they disapprove of the ghetto-specific behaviors of the blacks that live there. Being an ethnic black in interactions with whites seems to be a shorthand way of conveying distance from the ghetto blacks. Thus, the second generation reserves their ethnic status for use as an identity device to stress their distance from poor blacks and to stress their cultural values which are consistent with American middle-class values. This same use of an ethnic identity is present among first-generation immigrants of all social classes, even those in racially segregated poor neighborhoods in New York.

The second generation in the segregated neighborhoods, with little chance for social mobility, seems to be unaware that status as a black ethnic conveys higher social status among whites, in part because as of yet they have not had much contact with whites. The mass media conveys to them the negative image of American blacks held by whites, but does not convey to them the image among intellectuals, middle-class whites and conservative scholars, such as Thomas Sowell, that they have cultural capital by virtue of their immigrant status. They do get the message that blacks are stereotyped by whites in negative ways, that the all black neighborhoods they live in are violent and dangerous, and that the neighborhoods of whites are relatively safe. They also encounter a peer culture which values black American cultural forms. The immigrant culture of struggle, hard work and 
educational success that their parents try to enforce is experienced in negative ways by these youngsters. They see their parents denying them privileges that their American peers enjoy and, unlike the middle-class youth, they do not automatically associate hard work, lack of dating and partying, and stress on scholastic achievement with social mobility. In the peer culture of the school, immigrant and ethnic-identified teens tend to be the best students. In the neighborhood inner city schools, newly arrived immigrants who have attended better schools in the islands tend to out-perform the students who have spent their lives in the substandard New York City public schools. This tends to reinforce the association between ethnicity and school success - and the more American identified adopt an adversarial stance toward school. Warner and Srole (1945), in their study of Yankee City in the 1930s, report that it is the socially mobile white ethnics whose ties to the ethnic group and the ethnic identity decline. It is the individuals who are stuck in the lower classes who turn to their ethnic identities and groups as a sort of consolation prize:

Our class system functions for a large proportion of ethnics to destroy the ethnic subsystems and to increase assimilation. The mobile ethnic is much more likely to be assimilated than the non-mobile one. The latter retains many of the social characteristics of his homeland. . . Some of the unsuccessfully mobile turn hostile to the host culture, develop increasing feelings of loyalty to their ethnic traditions, become active in maintaining their ethnic subsystems, and prevent others from becoming assimilated. But, generally speaking, our class order disunites ethnic groups and accelerates their assimilation. (p. 284)

It could be that the process will be exactly the opposite for black immigrants and black ethnics. In this case, the more socially mobile cling to ethnic identity as a hedge against one's racial identity. The less mobile blacks see little advantage to stressing an ethnic identity in the social worlds in which they travel, which are shared mostly with black Americans. Stressing an ethnic identity in that context risks being described as "acting white," being seen as rejecting the race and accepting the white stereotypes which they know through their everyday lives are not true.

The changes in race relations in the United States since the 1960s are very complicated and most surely involve a mixing of class and race. Some white Americans are trying to see the difference between ghetto inner city blacks, whom they fear and do not like, and middle-class blacks, whom they do not fear and whom they would like to have contact with, if only to prove to themselves that they are not racist or, in a more formal sense, to meet their affirmative goals.

Middle-class blacks realize this and try to convey their class status to others in subtle and not so subtle ways (Feagin, 1991). The immigrants also utilize the fact that New Yorkers tend to use foreign-born status as a proxy for the class information they are seeking. The white New Yorkers we 
interviewed do notice differences among blacks, and they use ethnic differences as clues for class differences. If the association found here between social class and ethnic identity is widespread, this perception could become a self-fulfilling prophesy. It could be that the children of poor parents will not keep an ethnic identity and the children whose parents achieve social mobility will keep the ethnic identity. This will reinforce the image in the minds of whites that the "island people" are "good blacks," thus giving the edge in employment decisions and the like to ethnic blacks over American blacks.

On the other hand, it remains to be seen how long the ethnic-identified second-generation teens will continue to identify with their ethnic backgrounds. This is also related to the fact that whites tend to make racial judgements about identity when it comes to blacks. The second generation does not have an accent or other clues which immediately telegraph their ethnic status to others. They are aware that, unless they are active in conveying their identities, they are seen as black Americans and that often in encounters with whites the status of their black race is all that matters. It could be that by the time they have their children they will have decided that the quest not to be seen as a black American will be a futile one.

\section{REFERENCES}

Anderson, E.

1990 Streetwise: Race, Class and Change in an Urban Community. Chicago: University of Chicago Press.

Bonnett, A. W.

1990 "West Indians in the United States of America: Some Theoretical and Practical Considerations." In Emerging Perspectives on the Black Diaspora. Ed. A. Bonnett and G. L. Watson. Lanham, MD: University Press of America.

Bryce-Laporte, R.

1987 "New York City and the New Caribbean Immigration: A Contextual Statement." In Caribbean Life in New York City: Sociocultural Dimensions. Ed. C. R. Sutton and E. M. Chaney. New York: Center for Migration Studies.

1972 "Black Immigrants: The Experience of Invisibility and Inequality," Journal of Black Studies, 3:29-56.

Buchanan, S. H.

1979 "Language and Identity: Haitians in New York City," International Migration Review, 13:298-313.

Feagin, J. R.

1991 "The Continuing Significance of Race - Antiblack Discrimination in Public Places," American Sociological Review, 56(1):101-116.

Foner, $\mathrm{N}$.

1987 "The Jamaicans: Race and Ethnicity among Migrants in New York City." In New Immigrants in New York. Ed. N. Foner. New York: Columbia University Press. Pp. 131-158.

1985 "Race and Color: Jamaican Migrants in London and New York City," International Migration Review, 19:708-727. 
1985 "Race and Color: Jamaican Migrants in London and New York City," International Migration Review, 19:708-727.

Fordham, S.

1988 "Racelessness as a Factor in Black Students' School Success: Pragmatic Strategy or Pyrrhic Victory," Harvard Education Review, 58(1). February.

Gans, H.

1992 "Second Generation Decline: Scenarios for the Economic and Ethnic Futures of the Post-1965 American Immigrants," Ethnic and Racial Studies, 15(2). April.

Jensen, $\mathrm{L}$.

1990 "Children of the New Immigration: A Comparative Analysis of Today's Second Generation." University Park, PA: Pennsylvania State University Institute for Policy Research and Evaluation. Working Paper No. 1990-32.

Kasinitz, P.

1992 Caribbean New York: Black Immigrants and the Politics of Race. Ithaca, NY: Cornell University Press.

Lieberson, S.

1980 A Piece of the Pie: Blacks and White Immigrants Since 1880. Berkeley: University of California Press.

Massey, D.

1990 "American Apartheid: Segregation and the Making of the Underclass," American Journal of Sociology, 96(2):329-357. September.

Michael, S.

1990 "Children of the New Wave Immigration" In Emerging Perspectives on the Black Diaspora. Ed. A. V. Bonnett and G. L. Watson. Lanham, MD: University Press of America.

Ogbu, J.

1990 "Minority Status and Literacy in Comparative Perspective," Daedalus, 119(2):141168. Spring.

Portes, A. and M. Zhou

1993 "The New Second Generation: Segmented Assimilation and Its Variants," The Annals of the American Academy of Political and Social Science, 530:74-97. November.

Rumbaut, R. G.

1991 "The Agony of Exile: A Comparative Study of Indochinese Refugee Adults and Children." In Refugee Children: Theory, Research and Services. Ed. F. L. Ahearn, Jr., and J. L. Athey. Baltimore: The Johns Hopkins University Press.

Rumbaut, R. G. and K. Ima

1988 "The Adaptation of Southeast Asian Refugee Youth: A Comparative Study." Washington, DC: U.S. Office of Refugee Resettlement.

Stafford, S. B.

1987 "Language and Identity: Haitians in New York City." In Caribbean Life in New York City: Sociocultural Dimensions. Ed. C. R. Sutton and E. M. Chaney. New York: Center for Migration Studies.

Sutton, C. R.

1973 "Caribbean Migrants and Group Identity: Suggestions for Comparative Analysis. In Migration: Report of the Research Conference on Migration and Ethnic Minority Status and Social Adaption. Publication No. 5. Rome: United Nations Social Defense Research Institute. Pp. 133-148.

Sutton, C. R. and S. P. Makiesky

1975 "Migration and West Indian Racial and Ethnic Consciousness." In Migration and Development: Implications for Ethnic Identity and Political Conflict. Ed. H. I. Safa and B. M. Du Toit. Paris: Mouton and Co. 
Warner, W. L. and L. Srole

1945 The Social Systems of American Ethnic Groups. New Haven, CT: Yale University Press. Woldemikael, T. M.

1989 Becoming Black American: Haitians and American Institutions in Evanston, Illinois. New York: AMS Press. 